Јована Ј. Бркић*

Универзитет у Београду

Филолошком факултет
821.111(73).09 Делило Д. https://doi.org/10.18485/analiff.2019.31.1.1

Originalni naučni rad

Primljen: 12.04.2019

Prihvaćen: 18.07.2019

\title{
(НЕ)ПОПУЛАРНА КУЛТУРА У ПОСТМОДЕРНИСТИЧКОМ ОКВИРУ ДЕЛИЛОВОГ ПОДЗЕМЉА
}

Рад покушава да испита концепт популарне културе из више различитих аспеката и да сагледа како све популарна култура утиче на схватање савременог друштва који се у раду назива још и постмодернизмом. Два погледа на постмодернизам с фокусом на популарну културу која ће у овом раду бити представљена јесу нео-марксистички погледи Фредерик Џејмсона (Fredric Jameson) и Жан Бодријара (Jean Baudrillard) с једне, и про-постмодернистички поглед Линде Хачен (Linda Hutcheon) с друге стране. Коначно, рад покушава да покаже како ова два погледа недвосмислено указују на дијалектичку природу популарне културе и, најпосле, покушава да испита како се та природа манифестује у конкретном тексту, у овом случају, у ДеЛиловом роману Повземље.

Кључне речи: популарна култура, постмодернизам, Фредерик Џејмсон, Жан Бодријар, Линда Хачен, Дон ДеЛило, Поgземље

Како је Америка постала постмодерна?

На ово питање, одговор покушавају да дају многи, међу њима и чувени амерички писац, Дон ДеЛило (Don DeLillo). Иако у књижевним круговима и даље влада полемика око тога да ли је ДеЛило модерниста или постмодерниста, сасвим је извесно да он пише о постмодерном стању друштва. (Nel, 2008: 13-26) Стога можемо рећи да су нека од кључних питања ДеЛилове поетике следећа: како је грађење савременог америчког личног идентитета у вези са друштвеним и културним силама насталим током времена (2008: 13), и како се и да ли се амерички лични идентитет одваја од америчког нациналног иден-

*_ brkic.jovana@gmail.com 
Jovana Brkić

титета. Покушавајући да одговори на ова питања, ДеЛило показује не само како је Америка постала постмодерна, већ и како се појединац сналази у том новом свету који пред њега поставља неке нове изазове.

Када кажемо да се неко дело бави постмодерним друштвом и да припада постмодернизму, ваља поменути шта постмодерна и постмодернизам подразумевају. Кључну дистинкцију између постмодерне и постмодернизма даје Линда Хачен (Linda Hutcheon): први термин односи се на друштвени и филозофски период или „стање“ (Hutcheon, 2001: 23), док други подразумева начине на које се одређена култура изражава. (2001: 1) Период који обухвата постмодерна почиње, по мишљењу неких, почетком 60-тих када је почео и процват постмодерне архитектуре, док, по мишљењу других, крај Другог светског рата представља радикални прекид с модерном, тј. почетак постмодерне. Новом друштвеном периоду потребан је и нови културни израз, који се у литератури, сада већ званично, усталио као постмодернизам. Међутим, постмодернизам јесте један од оних термина који је прилично тешко дефинисати а да се притом не западне у извесне противречности. Иако неки не признају постмодернизам као правац, сматрајући да он није ништа друго до продубљени модернизам, не можемо порећи да између модернизма и постмодернизма постоје извесне разлике. Нову поетику одликује пре свега изразита самореференцијалност и само-рефлексивност, затим преиспитивање тзв. „великих прича“ и деконструкција концепта „дух времена“, опсежно коришћење ироније и пародије, укидање граница између „високе“ и „ниске“ културе и још много чега. Како се за потребе овог рада не можемо бавити свим аспектима постмодернизма, ограничићемо се на онај аспект који се тиче популарне културе, тј. њеног уплива у „високу“ културу, тј. брисања или, пак, померања граница између „високе“ и „ниске“ уметности. Да бисмо дотле стигли, потребно је да за почетак подробније дефинишемо термин „популарна култура“, да бисмо потом покушали да покажемо како је она послужила као потка за, с једне стране, критику постмодернизма, односно афирмацију постмодернизма као културног израза, с друге стране. Два погледа на постмодернизам с фокусом на популарну културу која ће у овом раду бити представљена јесу нео-марксистички погледи Фредерик Џејмсона 
(НЕ)ПОПУЛАРНА КУЛТУРА У ПОСТМОДЕРНИСТИЧКОМ ОКВИРУ ...

(Fredric Jameson) и Жан Бодријара (Jean Baudrillard) с једне ${ }^{1}$, и пропостмодернистички поглед Линде Хачен с друге стране. Коначно, покушаћемо да покажемо како ова два погледа недвосмислено указују на дијалектичку природу популарне културе и, најпосле, да испитамо како се та природа манифестује у конкретном тексту, у овом случају, у ДеЛиловом роману Пояземље.

\section{Популарна култура у постмодерном друштву}

Иако је кроз историју било пуно покушаја тумачења појма „културе“, од новијих можда је најзначајније тумачење антрополога Клифорда Герца (Clifford Geertz), чији је рад посебно утицао на стварање критичких школа попут новог историзма и културног материјализма. Герцов рад је иновативан по томе што он сматра да не постоје тзв. „Пре-културне универзалије“ - култура се не сагледава као скуп конкретних бихевиоралних шаблона, већ као скуп контролних механизама за управљање понашањем. Култура се, дакле, не објашњава неким спољним узроком, већ сопственим правилима и поретком. Герц је своју интерпретацију овако схваћене културе назвао „подробни опис“ који подразумева сложени поступак разумевања културе у свој њеној различитости. (Geertz, 1973: 3-33) „Подробно описивање“ могло би се објаснити као „интерпретативна прича“: она се усредсређује на неки догађај, и испитује све детаље како би се открио етос неке непознате културе. (1973: 3-33) Да би се неки текст „подробно описао“, потребно je, дакле, повезати га са другим културним феноменима једног доба.

Овакво схватање културе у први план ставља описивање које никада није коначно, јер непрестано мора узимати у обзир новонастале промене и догађаје. (Спремић, 2011: 18) Такође, мора се нагласити да се ни тумач који културу описује не налази изван ње. Опис културе je, дакле, подробан не само зато што трага за пуноћом конкретног догађаја, већ и зато што подразумева културну специфичност самог тумача. (2011: 18)

\footnotetext{
1 Иако Џејмсонова и Бодријарова тумачења постмодернизма, односно постмодерне културе, нису истоветна, одлучили смо да због многобројних сличности у тим тумачењима, али и због генерално негативног става који обојица заузимају према постмодерном друштву, њихова тумачења „здружимо“ под кровом нео-марксистичке поетике која се показала као један од главних „критичара“ постмодернизма као књижевно-филозофског правца.
} 
Jovana Brkić

Овако схваћена култура не представља, дакле, једну монолитну и непроменљиву структуру - култура је, наиме, непрекидни процес производње значења нашег друштвеног искуства, односно процес производње значења из нашег друштвеног искуства, а из тих значења неминовно происходи друштвени идентитет оних људи који су у тај процес укључени. (Fiske, 1996: 1) Стварање културе је, дакле, друштвени процес у који су укључени не само сви друштвени слојеви, већ и сви производи тих различитих слојева друштва. На овај начин губи се онај елитистички призвук који је реч „култура“ вековима са собом носила, негде све до почетка постмодерног доба - култура се више не налази само у музејима и вилама богатих, она излази на улице, увлачи се у најсиромашније квартове, постаје доступна свима.

Коначно је савремено доба направило места и за онај део културе који је вековима бивао деградиран и одбациван зарад очувања исконских и непроменљивих „естетских вредности“ - популарну културу. Популарна култура је, дакле, део културе у најширем смислу, с тим што је дуго заузимала подређено место у односу на доминантне културне матрице привилегованог, буржоаског слоја друштва, оне исте матрице које се односе на већ поменуте „естетске вредности“. Популарну културу, дакле, чине различите формације потлачених или обезвлашћених људи (1996: 1), те се у том смислу популарна култура јавља као агенс који је у директном конфликту са доминантном културном формацијом. Па ипак, од доминантне културе популарна култура није одвојена кинеским зидом - и једна и друга настају из истих друштвених извора, користе се истим дискурсима тих извора, с тим што их обрађују на различите начине. Ови дискурси преносе интересе доминантне идеологије (почевши од телевизије, преко модне индустрије, до самог језика), а у себи садрже хегемонске силе које раде у интересу одржавања статуса кво. (1996: 2) Како онда такве дискурсе може користити популарна култура?

Да би популарна култура извршила свој главни задатак - подрила доминантни поредак ${ }^{2}$ - она мора поседовати извесне структурне

2 Подривање или субверзију овде треба схватити на начин на који је то објаснио Стивен Гринблат (Stephen Greenblatt) у својој чувеној студији Самообликовање у ренесанси - субверзија не представља покушај рушења неког поретка ради успостављања новог поретка (за који ће се временом показати да није ништа бољи од претходног), већ подривање владајућег дискурса изнутра, чиме се свако мало доводе у питање начела на којима он почива. 
(НЕ)ПОПУЛАРНА КУЛТУРА У ПОСТМОДЕРНИСТИЧКОМ ОКВИРУ ...

сличности са поретком чије основе доводи у питање. Другим речима, ако би се одређени дискурс схватио као сасвим туђински, могао би се уништити, али се не би могао пародирати и тако суштински довести у питање. ${ }^{3}$ Популарна култура је, дакле, производ друштвено подређеног слоја људи која, парадоксално и подрива и потврђује доминантни културни дискурс. Или, како би се још могло рећи, субверзија је истовремено интегрисана оном истом моћи коју наизглед угрожава. (Гринблат, 2007: 161-186) Једино што преостаје јесте пронаћи механизме којима се може (без)болно супротставити владајућем поретку.

Популарна култура као субверзивни агенс није, међутим, исто што и масовна култура - као продукт капиталистичког друштва, масовна култура представља робу коју широке народне масе троше без икакве критичке свести о томе одакле потиче и зашто се уопште и пласира на тржиште. За разлику од ње, популарна култура није готов производ, већ непрекидни процес стварања и преношења значења,

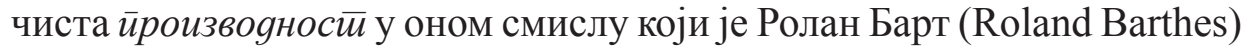
можда најбоље објаснио својим термином signifiance. Схваћена на овај начин, популарна култура показује да међу широким народним масама ипак постоји и она скупина људи која уме да мисли својом главом, а чија се критичка свест непрекидно потцењује и доводи у питање.

Које су главне одлике популарне културе? У свом делу Чийање йойларне кулйуре, Џон Фиск (John Fiske) даје преглед неких њених основних одлика: интензивна употреба игре речи, пародије, субверзије и инверзије, неретко вулгарни израз, контрадикторност, фокус на тело и телесна задовољства итд. (Fiske, 1996: 6) Она не претендује на објективни израз, увек је политички обојена и често игра активну улогу у друштвеним променама. Како је нераскидиво повезана са садашњим тренутком, услед брзог следа догађаја велики део популарне културе је кратког века (1996: 6) - па ипак, они сегменти популарне културе који опстану неко време, својим несвакидашњим изразом позивају на различита тумачења која се често настављају чак и онда када ти сегменти изгубе своју „популарност“.

3 О пародији ће више речи бити у поглављу „Критика Линде Хачен“ 


\section{Критика Бодријара и Џејмсона}

Марксизам као критика капиталистичког друштва извршио је огроман утицај и на теоретичаре друге половине двадесетог века који су у њему нашли ослонац за критику савременог друштва у којем су се и сами нашли, а које је, на Марксовом трагу, Џејмсон назвао „касни капитализам““. „Касни капитализам“, „,мултинационални капитализам“, „друштво кича и спектакла“, „медијски капитализам“, чак и „постмодернизам““4 - све су то синоними за онај временски период који почиње негде од друге половине двадесетог века, а које Џејмсон одбија да назове „постиндустријско друштво“ јер би такав назив подразумевао другачије схватање природе капитала (онако како се капитал схватао у деветнаестом веку и како га је Маркс описао).

Много тога Џејмсон замера постмодерном друштву, између осталог и сваки губитак историчности и схватање садашњости као пуке хетерогености. (Jameson, 1991: 6) Како је још са Жан-Франсоа Лиотаром (Jean-François Lyotard) Историја раскринкана као метанаратив, тако је, по Џејмсоновом схватању, отпочела екстремна релативизација свих вредности у друштву које се дотад нису доводиле у питање. Овакав преврат у мишљењу довео је до стања општег хаоса и збуњености, те се Џејмсон свим силама залаже за успостављање једне нове систематске културне норме. (1991: 6)

Како се сада популарна култура уклапа у овакво виђење света? Узмимо за пример сам почетак ДеЛиловог романа Поgземље, тачније пролог под називом „Тријумф смрти“. Писац нас увлачи у узаврелу атмосферу бејзбол утакмице у којој исцепане странице из часописа падају са трибина на терен, разнобојни папири на којима су слике хране за бебе и инстант кафе, репродукције Рубенса и Тицијана, најновије рекламе за плејтекс и моторолу, све то на једном месту, све део једне исте ствари. (ДеЛило, 2007: 39) Маса ни не примећује то ђубре које лети свуда унаоколо, тај живот у боји са страница магазина, исувише је обузета исходом утакмице. Међутим, маса то ни не може да примети, ДеЛило је тога свестан. Њему је потребан само један лик, Едгар Џ. Хувер, који ће се на секунд замислити над сликом која му се нашла под руком, репродукцијом Бројгеловог дела „Тријумф смр-

4 О Џејмсоновом пропусту да направи дистинкцију између постмодерне и постмодернизма говориће Линда Хачен у чувеној књизи Политика постмодернизма. О њеном схватању постмодерне и постмодернизма било је већ речи у уводу. 
(НЕ)ПОПУЛАРНА КУЛТУРА У ПОСТМОДЕРНИСТИЧКОМ ОКВИРУ ...

ти“ штампаној у часопису Лајф. Она је само део смећа које људи око њега бацају у жељи да постану нераскидиво повезани са једним историјским тренутком, победом Џајантса на шампионату. Она је део личног смећа, нечега што са собом носи сенку идентитета (2007: 45), трачак нечије приватности, а која бива бачена у суманутој жељи да се стопи у један општи догађај, да постане део једног колективног тренутка, део популарне културе у самом настанку. То што она приказује дело познатог фламанског сликара, сцене страдања и смрти, никоме осим Хуверу није важно - популарна култура слави ову победу, слави овај садашњи тренутак, а за то су јој потребна сва средства, репродукције познатих слика и ролне тоалет папира, без разлика, без привилегија.

Нема, дакле, више оне историчности у савременом добу, како Џејмсон примећује, а сцена на стадиону то савршено приказује - слике са страница магазина представљају културу која више не познаје или, пак, не прави разлику између високе и ниске уметности. Оног тренутка када се један Бројгел штампа у часопису који уредно прати живот Френка Синатре и деколте Аве Гарднер, а да то никоме не изгледа чудно или неадекватно, штавише, оног тренутка када неко чак и не успе да идентификује слику као дело чувеног уметника, почиње ера у којој интересовање за историју губи сваки смисао, те стога постаје све теже одредити шта одакле потиче, шта су копије а шта оригинали.

Очигледно је, дакле, да Џејмсон прилично негативно гледа на савремено доба и културу. Много је, међутим, теже одредити ДеЛилов став према култури коју приказује. Наиме, уколико се фокусирамо на већ поменуту сцену са стадиона, можда је право питање следеће: коју културу ДеЛило заправо приказује, масовну или популарну? Тешко је понекад направити разлику између њих, јер се обе служе актуелним производима културе у најширем смислу које потом обрађују и пласирају на тржиште у виду бејзбол утакмице или нове линије купаћих костима. Ако се послужимо већ поменутом дистинкцијом да је масовна култура готов, док је популарна култура производ у настанку, можемо рећи да ДеЛило истовремено слика обе: спортски догађај као део популарне културе у чијем настанку и развоју учествују сви, а који своје постојање делимично дугује производима масовне културе који су без размишљања одбачени зарад једног вишег циља. Бејзбол 
Jovana Brkić

утакмица тако улази у историју, постаје део културе једног народа, опште место које ће годинама касније многи евоцирати питањем: „Где си био када је Томсон истрчао хомера?“ (2007: 97) Па ипак, како се популарна култура критички односи према свету и себи самој, утакмица између Џајантса и Доџерса је у својој бити амбивалентна - док с једне стране симболизује невероватну победу, с друге стране подсећа на претњу која је лебдела у ваздуху, на нуклеарну пробу коју су Совјети истог дана када се и утакмица одржавала извршили на америчком тлу. Свакоме ко у потпуности схвати дијалектичку природу популарне културе, дакле, свакоме ко је, као Хувер или касније Марвин, „преозбиљно“ схвати (2007: 330), она се свети. Па ипак, наставиће даље ДеЛило, како популарну културу не схватити озбиљно, постоји ли ишта што би требало озбиљније схватити? (2007: 330) Ово реторичко питање критичари попут Џејмсона свакако не би очекивали. Уколико прихватимо чињеницу да још увек постоји одређени број људи који критички преиспитују време у којем живе, то би онда значило да не можемо у потпуности прихватити Џејмсонову тезу о сваком губитку историчности у савременом добу. Да, све је теже одредити шта одакле потиче, све је теже, али да ли је и немогуће?

Бодријар би вероватно рекао - немогуће је. Његова идеја да живимо у свету симулакрума послужиће као подлога свима који савремено доба виде у негативном светлу. И заиста, чини се да савремено доба слави владавину симулакрума, ма колико то застрашујуће деловало на моменте. Изложба Ејси Грин, младе поп-арт уметнице, прави је пример Бодријарове тезе да живимо у свету симулакрума. Она одлучује да слика не праве поп-арт иконе попут Мерилин Монро и Џејн Менсфилд, већ лажне Мерилин и Џејн, упаковане груди и напућене усне, масне блајхане плавуше, жене које цуре на све стране, жене које се разливају, атомске жене. $(2007: 483,493)$ Очигледно је да су оне копије, „репродуковане богиње“, како их ДеЛило назива (2007: 499), али то су репродукције које временом почињу да добијају такву снагу да постају моћније од оригинала уйраво зато што нису оригинали. (2007: 499) Другим речима, копије постају толико живе да почињу да постоје као симулакруми, ентитети који наизглед реферишу на нешто, а којима, заправо, недостаје референт. У свету у коме не можемо пронаћи порекло ствари, како би Бодријар рекао, тј. у свету у коме нема више историчности, како би Џејмсон рекао, лако је упасти у ши- 
(НЕ)ПОПУЛАРНА КУЛТУРА У ПОСТМОДЕРНИСТИЧКОМ ОКВИРУ ...

зофрено стање и параноју. Како не постоји ни један стабилан и неопозив ентитет наспрам чега бисмо одредили сопствено постојање, како онда изградити властити идентитет, како веровати у себе и не упадати све чешће у егзистенцијалне кризе? Чини се да Бодријарова и Џејмсонова критика овде показује своју највећу снагу - ако савремено доба све више разара људску егзистенцију, не би ли се онда требало отворено супротставити његовим начелима?

Много је, међутим, већи проблем пронаћи начине како се супротставити свету који је окренут наглавце. Читајући Бодријара и Џејмсона, стиче се утисак да смо већ изгубили битку, да је немогуће преокренути тренутно стање и да ћемо остати заувек заробљени у свету симулакрума. С друге стране, Линда Хачен сматра да постмодерна слика света није у потпуности тако црна - онде где Бодријар и Џејмсон не успевају да сагледају ништа више осим губитка историчности, масовне производње и пролиферације кича, она препознаје суптилно подривање начела на којима постмодерно друштво почива. Узмимо за пример део романа у коме ДеЛило приказује рад поп-арт уметнице Кларе Сакс, њен велики пројекат с авионима. Уколико бисмо остали на Бодријаровом и Џејмсоновом трагу, овај вид популарне уметности коју Саксова ствара био би ништа друго до експлоатација прошлости, коришћење прошлости без праве свести о томе шта она представља, тумачење прошлости на основу поп слика из прошлости чиме историја света постаје, како Џејмсон наводи, „поп историја“. (Jameson, 1991: 25) И заиста, чак и сама помисао на то да је неко озлоглашене бомбардере обојио у дречаве боје и читав пројекат назвао Дуїоноїа ви-

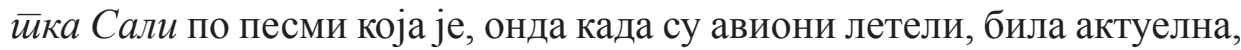
а које се, онда када се авиони боје, скоро нико и не сећа, као да у себи носи елемент преступа, као да читав овај уметнички подухват донекле скрнави прошлост и ниподаштава страхоте рата. Како на пројекту ради Клара са масом студената који носе мајице са стиховима песме коју никада нису чули и који имају само нејасну идеју о томе шта рат представља, овај уметнички, а не мировни подухват (ДеЛило, 2007: 72), како га Клара назива, делује донекле непримерено. Популарна култура, у овом случају Кларин пројекат, нема, дакле, никаквог обзира према прошлости, она, како то Џејмсон тврди, присваја оно што није њено (Jameson, 1991: 3) и то обрађује на начин који њој одговара. Бодријар би додао да смо, дакле, изгубили контакт с „реалним“ на 
више начина, да нам није преостало ништа осим непрестане фасцинације тим губитком. (Baudrillard, 1994: 154) Нашим властитим губитком, како потом наставља. (1994: 154)

У оваквом свету нема места супротстављању - свуда, увек, систем је исувише јак: хегемонски. (1994: 156) Међутим, да ли је то заиста тако, питају се неки, међу њима и Линда Хачен. Да ли је могуће да у свету у коме капитал игра улогу хегемона не постоји ништа што би се њему на тренутак супротставило? Наравно да постоји, рећи ће она, с тим што су те супротстављене силе латентне, оне поредак не подривају директно и отворено, већ суптилно и изнутра. Узмимо за пример исто поглавље о Кларином уметничком пројекту. Тешко је отети се помисли да је овај вид уметности много више од пуке експлоатације прошлости, као да постоји неки подтекст које би тек пажљивије читање могло открити. И заиста, читајући поглавље, долазимо до дела у коме Саксова објашњава свој рад као покушај супротстављања технолошкој култури за коју осећамо да „не смемо дозволити да нас покори“. (ДеЛило, 2007: 73) Неомарксисти свакако не би очекивали овакав степен трезвености и самосвести од популарне културе, можда управо зато што јој не признају статус који заслужује. Популарна култура, у овом случају рад Саксове, критички преиспитује прошлост и садашњост, она разоружава свет, али то чини „опрезно и трезвено и с пуном свешћу о томе чега се одричемо“. (2007: 79) Она не претендује на коначни суд, зато и није готов продукт, већ „дело у настајању“ које се „мења свакога дана и сваког минута“. (2007: 78) Симболично прозвана Сметларка, Клара чини оно што би сваки поп-арт уметник урадио - трага за одбаченом историјом у облику ђубрета у коме проналази опипљиву димензију живота. Смеће, један од централних мотива књиге, јесте ,јединствени културни талог“ (2007: 189), како га ДеЛило назива, нешто што цивилизацију уједно и дефинише и уништава. Историја, права историја, не налази се у књигама, већ на депонијама, под земљом, а само поједини неће окренути главе од смрада, већ ће у ту историју заронити и покушати да међу отпацима пронађу одбачене ствари, али и заборављене вредности једне цивилизације. Кларин пројекат јесте, дакле, опомена човечанству, не само шарлатанско поигравање прошлошћу како би то критичари попут Бодријара и Џејмсона протумачили. Као и сваки вид популарне уметности, он скреће пажњу на себе својим дречавим изгледом, али и поруком коју носи, 
(НЕ)ПОПУЛАРНА КУЛТУРА У ПОСТМОДЕРНИСТИЧКОМ ОКВИРУ ...

а коју је понекад тешко разазнати у том шаренилу у којем обитава. Управо је зато популарна култура толико провокативна, будудући да, у исто време, и привлачи и одбија. Међутим, уколико не би задржала овај амбивалентни статус, недостајала би јој она филозофска димензија која је неопходна свакој уметности да постане „велика“.

\section{Критика Линде Хачен}

Како у постмодерном добу више нема неопозивих вредности на које се можемо позивати, сваки покушај отвореног супротстављања разобличава се као нови тип метанаратива, а Џејмсонова и Бодријарова критика упадају управо у ову замку. Другим речима, ако се већ нечему треба супротставити, то треба чинити на суптилан начин, латентно и изнутра. Ово је уједно и став Линде Хачен која се, додуше, слаже са Џејмсоном и Бодријаром онда када је њихова критика упућена на опште стање духа у постмодерном друштву, али која не може а да не примети неке од мањкавости њихових теорија.

Оно што Хаченова највише замера Џејмсону јесте његов пропуст да направи разлику између постмодерне и постмодернизма. ${ }^{5}$ Како и сама наводи, Џејмсон намерно и упорно назива постмодернизмом оно што је заправо, по њеном мишљењу, постмодерна. (Hutcheon, 2001: 25) Ова дистинкција је, међутим, кључна за Хаченову јер би без ње свака критика савременог друштва била немогућа. Наиме, уколико би се постмодернизму као културном изразу једне епохе укинуо тај статус, како је онда могуће критички сагледати савремено доба? Одиста, она признаје да не постоји културни израз који није идеолошки утемељен (2001: 3), али то не значи да је културни израз исто што и сама идеологија. Постмодернизам је, дакле, културна пракса која на известан начин произилази из постмодерне (сама сличност у називу довољан је показатељ њихове блискости) (2001: 26), али која задржава свој, донекле аутономни статус и која, стога, може то исто друштво чији је и сама продукт критиковати.

Популарна култура се, као што је већ речено, јавља као један од главних агенаса у подривању доминантних културних матрица. ДеЛило је тога свестан, те зато треба пажљиво ишчитавати оне делове романа у којима обрађује различите аспекте популарне културе. Уз-

5 О њеном схватању термина постмодерна и постмодернизам, било је речи у уводу. 
Jovana Brkić

мимо за пример део у коме говори о уличној уметности цртања графита. Графити су много више од обичне слике на зиду, они причају причу о животу у сиротињским зградама, дилерима дроге, деци која прерано одлазе у криминал, деци која и немају право детињство, болестима и оружју, убиствима и силовањима. То су приче које већини људи делују потпуно надреално, које их вуку да из пуке знатижеље туристичким аутобусима посећују Наяреалистиччки јужни Бронкс, како га зову, а који је заправо много стварнији од једног Милана или Брисела. (ДеЛило, 2007: 251) Цртачима графита, као ДеЛиловом Исмаилу Муњосу познатијем као Мунмену 157, главни задатак постаје тај да ту уметност улице прикажу свима, нарочитио онима који не желе да је виде. Свет више не може а да их не види, не може а да не зна ко су они, њихова уметност постаје славна, а што је најважније, они је се више не стиде, напротив. (2007: 449) Цртање графита тако постаје уметност, иррава уметност, која не зна за мировање, која се ноћу и дању увлачи у очне јабучице; то је уметност сламова и сметлишта која шиба бојама по лицу, као да хоће да каже да је она филм који сви ми треба да гледамо. (2007: 449)

Графити као вид популарне уметности носе јасну поруку људи из подземља: иако их је друштво гурнуло на маргину да би могло да неометано и без гриже савести ужива у трошењу свог капитала, ти

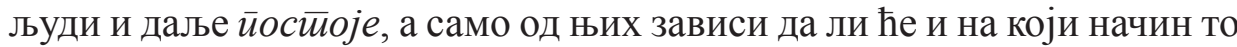
осталима ставити до знања. Као и смеће које се одлаже по депонијама што даље од градова, људи са маргина представљају друштвени отпад кога треба учинити што невидљивијим, ако је већ немогуће потпуно га се отарасити. Аналогија са отпадом није случајна - иако ДеЛило нигде експлицитно не говори о људима из сиротињских четврти као о смећу, изгледа готово немогуће не довести их у везу. Људи са маргине и смеће су на симболичном плану иста ствар - тајна историја, подисторија (2007: 799), како је ДеЛило назива, која се враћа да нас прогута онда када смо помислили да смо је склонили довољно далеко, закопали довољно дубоко. Управо је зато од изузетне важности бавити се том историјом, ма колико она непријатно изгледала, јер на њој почива будућност читавог света. Међутим, ретки су они који се том историјом баве, толико ретки да личе на припаднике једног езотеричног реда, адепте и пророке (2007: 189) који својим критичким сагледавањем садашњег тренутка предвиђају будућност. Доиста, 
(НЕ)ПОПУЛАРНА КУЛТУРА У ПОСТМОДЕРНИСТИЧКОМ ОКВИРУ ...

Кларино копање по смећу или њена махнита потрага за Исмаилом по неугледним четвртима Бронкса на тренутке делују готово сумануто; па ипак, много чешће се у тим поступцима наслућује неки смисао који тек временом постаје транспарентан и за остатак друштва. Популарна култура, у овом случају уметност цртања графита, обраћа се, дакле, свима - сваким осликаним возом подземље нас подсећа да није мртво и мирно, да је оно сила која се не може угушити и да зато престанемо да је негирамо. Па ипак, само поједини су спремни да ту културу признају као легитимну, те стога и иступају као визионари који имају ону гипкост духа која је потребна да се свет сагледа у свој различитости, без икаквих критика и осуда.

Различитост на којој свет почива је, међутим, најтеже прихватити. Џејмсонова критика постмодерне иде управо у том правцу превише је све у савременом друштву различито, све је допуштено и све се меша, нема више никаквих норми и правила, све је само један велики пастиш. Према Џејмсону, пародију је у постмодерном добу заменио пастиш: као и пародија, пастиш представља имитацију нечег јединственог, идиосинкратичног; међутим ова имитација је неутралног типа, без скривеног смисла и сатиричног призвука који су својствени пародији. (Jameson, 1991: 17) Штавише, за Џејмсона је пародија „празна пародија“ (1991: 17) - како више нема историчности, пародија не може пародирати. Другим речима, ако више не можемо установити оригинале, како их онда доводити у питање?

Хаченова тврди да можемо. Проблем је, наиме, у искривљеном схватању појмова као што су „оригинал“, „реалност“, „историја“ итд. - они нису престали да постоје, како Бодријар тврди, већ су једноставно променили свој статус, тј. израсли су у појмове који више не могу сами себе објаснити и потврдити. (Hutcheon, 2001: 34) Постмодерна није, дакле, дегенерација у хиперреалност, како то Бодријар види, већ преиспитивање онога што реалност означава и начина на које је спознајемо. (2001: 34) И одиста, пита се Хаченова, јесмо ли икада познавали „реално“ ван његових репрезентација? (2001: 33) Наше претпоставке о ,реалном“ зависе од начина на који је оно представљено, како је смештено у дискурс и како се тумачи. (2001: 33) Нема, дакле, ничег природног у вези са „реалним“, нема га и никада га није ни било - чак ни пре појаве мас-медија које Бодријар криви за почетак ере симулакрума. (2001: 33) Сходно томе, и Џејмсонова теза 
Jovana Brkić

да је савремено доба изгубило осећај за историчност се мора преформулисати - и даље се може и жели приступити прошлости, али је сама прошлост разобличена као текстуални конструкт којој можемо приступити увек и само посредно. Постмодерна уметност прихвата, дакле, изазов традиције - од прошлости као репрезентације не може се побећи, али се она може критички реконструисати уз помоћ ироније и пародије (2001: 58) које савременом тексту обезбеђују преко потребну оригиналност и аутентичност.

И заиста, нема ли веће пародије од оне које из вечери у вече приређује Лени Брус, познати комичар кога ДеЛило смислено уводи у свој свет фикције. У тренутку када је земља престрављена због могућег атомског напада, потребан је ироничан поглед на читаву ситуацију који, парадоксално, и прочишћује од страха и тај страх обелодањује. (ДеЛило, 2007: 516) Лени мора непрестано да другима али и себи понавља реченицу: „Сви ћемо да изгинемо“ (2007: 516). У тој реченици крије се сва иронија савременог живота - можда је све само још један медијски спектакл, афирмација кенедијевских година у којима је све постало могуће и у којима су чврсто утврђене категорије почеле да делују неважно (2007: 582); а можда је овај пут читав тај спектакл једна застрашујућа истина која долази као опомена друштву које је изгубило сваки вредносни компас. Нико више није сигуран ни у шта, а потребна је једна, наизглед крајње једноставна, а опет толико вишезначна формулација - Сви ћемо да изгинемо! - да покаже сву нелагоду постмодерног друштва. У том свету нико није поштеђен, чак ни онај који га пародира - отуда и Ленијево инсистирање на томе да ће сви изгинути, укључујући и њега самог. Другим речима, нема безинтересног погледа „ни од куда“, пародија је увек и свуда политички утемељена. Сходно томе, транспарентност нечије идеолошке позиције омогућава и демистификацију исте, односно пружа простора да се у будућности та иста позиција искористи као материјал из прошлости који се даље може пародирати. Зато је пародија један од кључних механизама постмодернизма - захваљујући њој, тврди Хаченова, постмодернизам се не може више схватати само као безинтересно коришћење прошлости без свести о томе шта она заиста представља. Постмодернистичка пародија је, заправо, једна покретачка снага чија је природа дијалектичка - као и Ленијев крик, она је на моменте патетична и кукавичка, али исто тако и узвишена у свом 
(НЕ)ПОПУЛАРНА КУЛТУРА У ПОСТМОДЕРНИСТИЧКОМ ОКВИРУ ...

наивном покушају обрачунавања са светом јер у себи носи зрнце неодољивог и вечитог пркоса. (2007: 557)

\section{Закључак}

„Највеће су тајне оне које се широм отварају пред нама“ (2007: 189), рећи ће ДеЛило. И заиста, популарна култура нас свакодневно окружује, а опет је понекад јако тешко проникнути у њену природу. Јер, како је и сама део културе у најширем смислу, оне културе коју одликује масовна производња и потрошња, а коју Џејмсон назива „касни капитализам“, тешко је одредити границу где престаје разумно промишљање и почиње потрошачка манија. Међутим, иако нас тера да трошимо, капиталистичко друштво нам ипак оставља избора - упркос притисцима са свих страна, људи су ти који, најпосле, бирају које ће производе културе користити. (Fiske, 1996: 5) Можемо зато рећи да је популарна култура настала као свестан одабир одређених културних аспеката који, здружени, умеју да одају утисак бесмисла, али који пажљивијом анализом откривају своја „скривена“ и „смислена“ значења.

Па ипак, капитал уништава све нијансе у једној култури (ДеЛило, 2007: 793), рећи ће на крају романа Поgземље ДеЛило. Тачно је, додаје он, да не морамо желети сви исте ствари, али не желимо ли сви ми, најпосле, исти опсег избора? (2007: 793) Није ли популарна култура, дакле, само још једна илузија, наше наивно уверење да имамо оружје за борбу против опресивног капитализма? Или је, пак, она покушај ироничног сагледавања тог опсега избора - доиста, он је за све исти, али зашто би нас то спречавало да се њиме поиграмо, да изнова ре-конструишемо дате културне матрице? Како год, популарна култура нам се представља у својој амбивалентној природи, а на нама је да одлучимо желимо ли је такву прихватити, са свим њеним опречним значењима, са свим (не)усклађеним нијансама.

\section{ЛИТЕРАТУРА}

Barthes, R. (1981). The Theory of the Text. In R. Young (ed.), Untying the Text (pp. 31-47). London: Routledge \& Kegan Paul.

Baudrillard, J. (1994). Simulacra and Simulation. Translated by Sheila Glaser. University of Michigan Press. 
ДеЛило, Д. (2007). Пояземье. Превео: Зоран Пауновић. Београд: Геопоетика. Fiske, J. (1996). Understanding Popular Culture. London and New York: Routledge.

Geertz, C. (1973). The Interpretation of Cultures. New York: Basic Books.

Гринблат, С. (2007). Невидљиви меци: субверзија власти у ренесанси. У Д. Шпорер (ур.), Поеииика ренесансне кулииуре: нови хистиоризам (161186). Загреб: Диспут.

Гринблат, С. (2011). Самообликовање у ренесанси. Превеле: Невена Мрђеновић и Јелена Стакић. Београд: Клио.

Hutcheon, L. (2001). The Politics of Postmodernism. London and New York: Routledge.

Jameson, F. (1991). Postmodernism or the Cultural Logic of Late Capitalism. Durham, NC: Duke University Press.

Nel, P. (2008). DeLillo and Modernism. In J. N. Duvall (ed.), The Cambridge Companion to Don DeLillo (pp. 13-26). New York and Cambridge: Cambridge UP.

Спремић, М. (2011). Полииикка, субверзија, моћ: новоисиооријска ииумачења Шексйирових великих ӣраїеgија. Београд: Задужбина Андрејевић.

\section{Jovana J. Brkić}

\section{(UN)POPULAR CULTURE IN THE POSTMODERN(IST) FRAMEWORK OF DELILLO'S UNDERWORLD}

\section{Summary}

The aim of the paper is to question the concept of popular culture from various aspects and to determine the ways in which popular culture influences the understanding of the contemporary world also reffered to as postmodernism in the paper. The two views on postmodernism which focus on popular culture and which will be presented in this paper are the neo-Marxist views of Fredric Jameson and Jean Baudrillard on the one hand and the pro-postmodernist view of Linda Hutcheon on the other hand. Finally, the paper aims at pointing out how the two views unequivocally manifest the dialectic nature of popular culture and it also strives to examine how the nature in question is disclosed in a text, in this case, DeLillo's novel Underworld.

Key words: popular culture, postmodernism, Fredric Jameson, Jean Baudrillard, Linda Hutcheon, Don DeLillo, Underworld 